\title{
Synthesis of $\left(2^{\prime}-5^{\prime}\right)$-triadenylates and their analogues using O-nucleophilic catalysis of internucleotide coupling reaction
}

\author{
I. Ya. Dubey, L. V. Dubey
}

Institute of molecular biology and genetics NAS of Ukraine Academicain Zabolotnog str., 150, Kyiv, 03680 Ukraine

e-mail: dubey@imbg.org.ua

$\left(2^{\prime}-5^{\prime}\right)$-triadenylate and its analogues containing $3^{\prime}$-terminal epoxyadenosine or cordycepin residue were obtained by phosphotriester approach in the presence of 4-ethoxypyridine $N$-oxide (EPO) as O-nucleophilic catalyst of coupling reaction. The coupling reactions proceeded with high speed (below 5 min) and efficiency (yield 86-92\%). The reaction yields achieved in the presence of $N$-methylimidazole were substantially lower (80-85\%), and the final yields of triadenylates were only 21-25\%, as compared to 29-35\% obtained with $\mathrm{N}$-oxide.

Keywords: (2'-5')-oligoadenylates, oligonucleotide analogues, phosphotriester synthesis, nucleophilic catalysis, pyridine $N$-oxides

Introduction. $2^{\prime}-5^{\prime}$-oligoadenylates (2-5A) play the key role in the mechanism of antiviral activity of interferon. The presence of $2-5 \mathrm{~A}$ is of great importance in the processes of cell growth and differentiation, apoptosis, pathogenesis of diabetes and atherosclerosis, moreover, they are considered to be very promising preparations for tumor and hematological diseases [1-5]. Unfortunately, natural $\left(2^{\prime}-5^{\prime}\right)$-oligoadenylates 1a (Figure) are rapidly cleaved in the cell by phosphodiesterases. 2-5A analogues with chemical modifications, including those that increase the nuclease resistance, often reveal higher biological activity. A broad variety of 2-5A analogues with modified carbohydrate residues, internucleotide phosphates, and heterocyclic bases has been obtained [1, 2, 6-12].

(C) I. Ya. DUBEY, L. V. DUBEY, 2007
Thus, triadenylate $1 \mathrm{~b}$ modified with epoxyadenosine is known to be the inhibitor of post-transplantation tissue rejection [12] and was shown to possess cardioprotecting features [13]. Adenylate 1a and its analogue $1 \mathrm{~b}$ stimulate proliferation of bone marrow stem cells and influence their apoptosis [14]. It was previously shown that oligoadenylates are closely connected with cAMP system (cyclic adenosine monophosphate) [15]. Type 1c analogues containing cordycepin (3'-deoxyadenosine) demonstrate antiviral activity, in particular against HIV-1 virus $[16,17]$. The mechanism of their antiviral activity includes activation of RNAse L [17], inhibition of reverse transcriptase [16], and DNA-polymerase [17]. Antiproliferative activity of cordycepin analogues of $2-5 \mathrm{~A}$ is connected with the activation of natural killer cells [18] and activity of nucleoside metabolites of "core" oligomers [19]. 


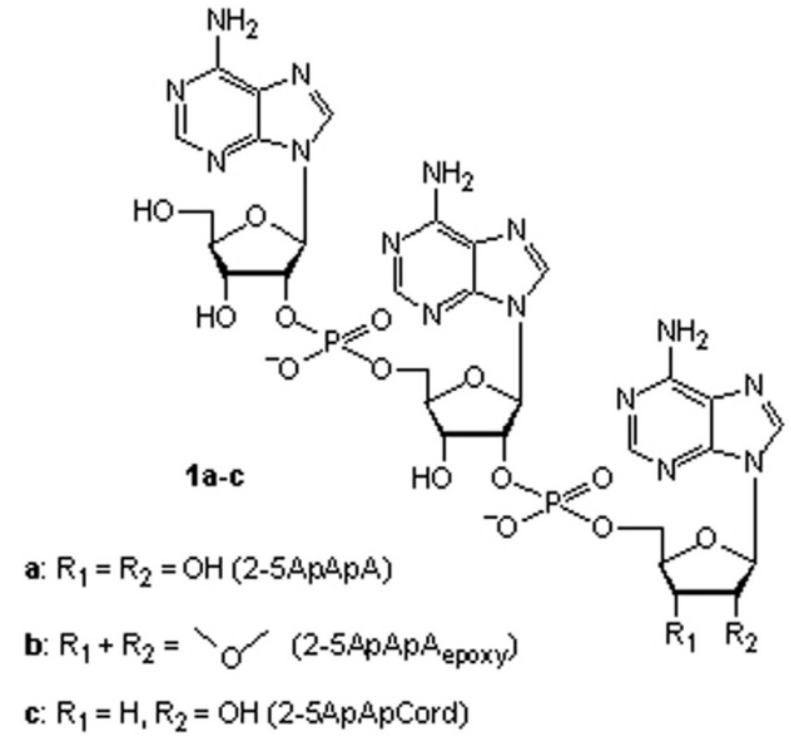

Structure of triadenylates

Most often 2-5A are prepared by phosphotriester synthesis in the solution, yet solid-phase phosphoramidite approach is also used to synthesize $2-5 \mathrm{~A}$ in small quantities $[1,2]$. Usually arylsulfonyl chlorides and nitrotriazolides are used in the presence of $\mathrm{N}$-methylimidazole or tetrazole catalysts as coupling reagents in phosphotriester method. Pyridine N-oxides, especially those containing $\pi$-electronodonor groups at para-position, are so called hypernucleophiles which catalyze acyl, phosphoryl and sulfonyl transfer reactions efficiently [20]. N-oxide-based reagents were proposed as coupling reaction catalysts in the synthesis of oligodeoxyribonucleotides [21-23]. Current work describes the first synthesis of 2-5A using O-nucleophilic catalysis. We have developed an efficient method of the preparation of $\left(2^{\prime}-5^{\prime}\right)$-triadenylates and their analogues $1 \mathrm{a}-\mathrm{c}$ by phosphotriester approach with 4-ethoxypyridine $\mathrm{N}$-oxide (EPO) as a coupling reaction catalyst.

Materials and Methods. Experiments were performed using adenosine (Fluka, Germany), $4,4^{\prime}$-dimethoxytrityl chloride, 2,4,6-triisopropylbenzenesulfonyl chloride (TPSCL), trimethylchlorosilane,

2-chlorophenyldichlorophosphate,

2-nitrobenzaldoxime (Alrdich USA). Other reagents and solvents were purchased from Macrochim, Ukraine. Acetonitrile was distilled over $\mathrm{P}_{2} \mathrm{O}_{5}$ and cal- cium hydride; pyridine was dried by distillation over $\mathrm{NaOH}$, ninhydrin and calcium hydride. ${ }^{1} \mathrm{H}$ NMR spectra were obtained on Bruker WM-300 spectrometer (300 MHz, internal standard tetramethylsilane), UV spectra were recorded using Specord UV-Vis spectrophotometer (Karl Zeiss Jena, Germany). Mass-spectra were obtained on Perkin-Elmer SCIEX API-100 instrument using electrospray ionization technique, ESI-MS, with detection of positive ions. Thin layer chromatography was performed on Silica gel $60 \mathrm{~F}_{254}$ plates (Merck, Germany) in the following systems: chloroform-methanol 9:1 (A), isopropanol-concentrated $\mathrm{NH}_{3}-$ water 5:1:2 (B). High performance liquid chromatography (HPLC) was performed on Waters system (USA) equipped with DAD-440 Kontron detector, using Nucleosil-C18 column $(10 \mu \mathrm{m}, 4.6 \times 250 \mathrm{~mm}$, Interchrom, France) in the gradient of $\mathrm{CH}_{3} \mathrm{CN}(5-40 \%)$ in $0.1 \mathrm{M}$ triethylammonium acetate buffer $(\mathrm{pH} 6.5)$. EPO was synthesized according to [24, 25]. Nucleotide component 2 was prepared by phosphorylation of 6-N,3'-O-dibenzoyl-5'-O-dimethoxytrityladenosine $[26,27]$ with $o$-chlorophenylphosphoditriasolide using standard procedure [28].

6-N-benzoyl-9-(2,3-anhydro- $\beta$-D-ribofuranosyl)a denine (3b)

2',3'-anhydroadenosine [29] (498 mg, $2 \mathrm{mmol}$ ) was evaporated with dry pyridine $(2 \times 5 \mathrm{ml})$, dissolved in 10 $\mathrm{ml}$ of the same solvent and trimethylchlorosilane was added (762 $\mu$ l, $6 \mathrm{mmol})$. The mixture was stirred for 5 hours at room temperature, benzoyl chloride $(464 \mu 1,4$ mmol) was added and left overnight. The mixture was cooled to $\sim 5^{\circ} \mathrm{C}$, then $2 \mathrm{ml}$ of water, and 10 min later 4 $\mathrm{ml}$ of $25 \%$ of aqueous ammonia were added. In $15 \mathrm{~min}$ the mixture was evaporated, and the residue was co-evaporated with $5 \mathrm{ml}$ of pyridine. Then $50 \mathrm{ml}$ of chloroform were added, the precipitate was filtered off, washed with $\mathrm{CHCl}_{3}(2 \times 10 \mathrm{ml})$, and filtrate was evaporated. The product was isolated by silica gel chromatography in the gradient of methanol $(0-8 \%)$ in chloroform. Product $3 \mathrm{~b}$ was crystallized from ethanol. $522 \mathrm{mg}$ of white powder were obtained (74\%). M.p. $186-187^{\circ} \mathrm{C}$ (lit. data $185-188^{\circ} \mathrm{C}$ [12]). ${ }^{1} \mathrm{H}$ NMR $\left(\mathrm{DMSO}-d_{6}\right): \delta 11.20$ (br.s, $\left.1 \mathrm{H}, \mathrm{NH}\right), 8.77$ (s, 1H) and $8.65(\mathrm{~s}, 1 \mathrm{H})(\mathrm{H}-2, \mathrm{H}-8), 8.06(\mathrm{~d}, \mathrm{~J}=6.9 \mathrm{~Hz}, 2 \mathrm{H}, \mathrm{Bz})$, 7.5-7.7 (m, 3H, Bz), 6.35 (s, 1H, H-1'), $5.06(\mathrm{~m}, 1 \mathrm{H}$, 5'-OH), 4.57 (br.s, 1H, H-2'), 4.26 (m, 2H, H-3', H-4'), 
3.56 (m, 2H, H-5',5"). Found, \%: C 57.46, H 4.38, N 20.05. Calculated for $\mathrm{C}_{17} \mathrm{H}_{15} \mathrm{~N}_{5} \mathrm{O}_{4}, \%$ : C 57.80, H 4.28, N 19.72.

Adenylyl-(2'-5')-adenylyl- $\left(2^{\prime}-5^{\prime}\right)-\left(2^{\prime}, 3^{\prime}\right.$-anhydroad enosine)(1b). Synthesis using EPO.

P-component 2 (1.34 g, $1.25 \mathrm{mmol})$, OH-component $3 \mathrm{~b}(353 \mathrm{mg}, 1 \mathrm{mmol})$ and EPO (1.31 g, $9.4 \mathrm{mmol})$ were evaporated with dry pyridine $(2 \times 10 \mathrm{ml})$, dissolved in $10 \mathrm{ml}$ of dry pyridine and TPSCl $(948 \mathrm{mg}, 3.13$ mmol) was added. In 5 min the reaction mixture was diluted with $50 \mathrm{ml}$ of chloroform and washed with aqueous $\mathrm{NaHCO}_{3}(2 \times 30 \mathrm{ml})$ and water $(30 \mathrm{ml})$, organic layer was dried over anhydrous $\mathrm{Na}_{2} \mathrm{SO}_{4}$ and evaporated in vacuum. Excess pyridine was removed by evaporating with toluene $(2 \times 10 \mathrm{ml})$. Dinucleotide $4 \mathrm{~b}$ was isolated by silica gel chromatography in the gradient of methanol in chloroform (0-3\%). $1.18 \mathrm{~g}$ of dimer $4 \mathrm{~b}$ was obtained (yield 91\%). It was dissolved in $75 \mathrm{ml}$ of $2 \%$ solution of $p$-toluenesulfonic acid (TsOH) in chloroform-methanol (7:3) mixture. In 5 min the mixture was diluted with $50 \mathrm{ml}$ of chloroform and washed with aqueous $\mathrm{NaHCO}_{3}(3 \times 50 \mathrm{ml})$ and water $(50 \mathrm{ml})$, organic layer was dried over $\mathrm{Na}_{2} \mathrm{SO}_{4}$ and evaporated. Detritylated dimer $5 \mathrm{~b}$ was isolated by silica gel chromatography in the gradient of methanol (0-3\%) in chloroform to get $820 \mathrm{mg}$ of the product (90\%). $820 \mathrm{mg}$ of $5 \mathrm{~b}$ (0.82 mmol), $1.10 \mathrm{~g}$ of P-component $2(1.03 \mathrm{mmol})$, and $1.08 \mathrm{~g}$ of EPO $(7.74 \mathrm{mmol})$ were evaporated with absolute acetonitrile $(2 \times 10 \mathrm{ml})$, dissolved in $10 \mathrm{ml}$ of this solvent, and TPSCl (782 mg, $2.58 \mathrm{mmol})$ was added. In 5 min the mixture was diluted with $50 \mathrm{ml}$ of chloroform, washed with aqueous $\mathrm{NaHCO}_{3}(2 \times 25 \mathrm{ml})$ and water $(25 \mathrm{ml})$, organic layer was dried over $\mathrm{Na}_{2} \mathrm{SO}_{4}$ and evaporated. After silica gel chromatography in the $0-3 \%$ methanol gradient in chloroform, $1.38 \mathrm{~g}$ of fully protected trimer was obtained $(86 \%)$. It was dissolved in $75 \mathrm{ml}$ of $2 \% \mathrm{TsOH}$ solution (chloroform-methanol 7:3). In $5 \mathrm{~min}$ the mixture was treated as described above, and detritylated trimer was isolated by silica gel chromatography in the gradient of methanol (0-3.5\%) in chloroform. The yield of the product was $1.03 \mathrm{~g}(0.62$ mmol, $88 \%$ ). $2.08 \mathrm{~g}$ of 2-nitrobenzaldoxime (12.5 $\mathrm{mmol})$ and dioxane, triethylamine and water $(30 \mathrm{ml}$ each) were added, and the solution was kept overnight at room temperature. The mixture was evaporated; the residue was evaporated with $10 \mathrm{ml}$ of pyridine and treated with $100 \mathrm{ml}$ of ether. The precipitate was filtered, washed with ether and dried in vacuum. It was dissolved in $50 \mathrm{ml}$ of conc. aqueous ammonia and left for $48 \mathrm{~h}$ at room temperature. The solution was evaporated, the residue was treated with $20 \mathrm{ml}$ of ether and 20 $\mathrm{ml}$ of $0.01 \mathrm{M}$ triethylammonium bicarbonate (TEAB, $\mathrm{pH}$ 7.5) and aqueous layer was separated. Trimer $1 \mathrm{~b}$ was isolated by chromatography on Molselect DEAE-25 sorbent (Reanal, Hungary, $\mathrm{HCO}_{3}^{-}$form) in the gradient 0.01-0.3 M TEAB (pH 7.5). Corresponding fractions were evaporated in vacuum, then evaporated with ethanol $(3 \times 20 \mathrm{ml})$. The residue was dissolved in the minimum volume of ethanol and precipitated with saturated potassium iodide solution in acetone $(200 \mathrm{ml})$. Potassium salt was filtered, washed with acetone $(5 \times 5 \mathrm{ml})$ and dried. The yield of $1 \mathrm{~b}$ was $344 \mathrm{mg}(0.35 \mathrm{mmol})$. Yield after deblocking equaled $56 \%$, overall yield was $35 \%$ based on starting OH-component $3 b . \mathrm{R}_{\mathrm{f}} 0$ (A), 0.72 (Б). UV $\left(\mathrm{H}_{2} \mathrm{O}\right): \lambda_{\max } 259 \mathrm{~nm}$ $\left(\varepsilon=3.73 \cdot 10^{4}\right)$. ESI-MS: $m / z 908.3\left[(\mathrm{M}+\mathrm{H})^{+}\right]$.

Adenylyl-(2'-5')-adenylyl-(2'-5')-adenosine (1a). Synthesis using MeIm.1.45 g (2.50 mmol) of OH-component 3a, $3.34 \mathrm{~g}$ ( $3.13 \mathrm{mmol})$ of P-component 2 and $2.24 \mathrm{ml}(28 \mathrm{mmol})$ of MeIm were evaporated with dry pyridine $(2 \times 20 \mathrm{ml})$, dissolved in $30 \mathrm{ml}$ of dry pyridine and TPSCl was added ( $2.85 \mathrm{~g}, 9.4 \mathrm{mmol})$. In $15 \mathrm{~min}$ the mixture was treated as described for 1a. Protected dinucleotide $4 \mathrm{a}$ was isolated by silica gel chromatography in the gradient of methanol in chloroform $(0-2 \%)$ to get $3.40 \mathrm{~g}(2.08 \mathrm{mmol}, 83 \%)$ of $4 \mathrm{a}$. It was dissolved in $200 \mathrm{ml}$ of $\mathrm{CHCl}_{3}-\mathrm{MeOH} 7: 3$ mixture, $3.95 \mathrm{~g}$ of TsOH (20.8 mmol) were added and the mixture was kept for 5 min. After the standard work-up the product was isolated by chromatography in the gradient of methanol $(0-2 \%)$ in $\mathrm{CHCl}_{3}$. The yield of detritylated dimer 5 a was $2.34 \mathrm{~g}(1.76 \mathrm{mmol}, 85 \%)$. P-component 2 (2.35 g, 2.2 mmol, 1.25 eq.) and $1.58 \mathrm{ml}$ of methylimidazole (19.8 mmol) were added and the mixture was evaporated with absolute $\mathrm{CH}_{3} \mathrm{CN}(2 \times 20 \mathrm{ml})$, dissolved in $30 \mathrm{ml}$ of the same solvent and $2.0 \mathrm{~g}$ of TPSCl $(6.6 \mathrm{mmol})$ were added. In 15 min the mixture was treated as described above. Chromatography in the gradient $0-2 \% \mathrm{MeOH}$ in chloroform allowed obtaining $3.21 \mathrm{~g}(1.41 \mathrm{mmol}, 80 \%)$ of fully protected trimer. It was detritylated by the treatment with $2.68 \mathrm{~g}$ of TsOH $(14.1 \mathrm{mmol})$ in $150 \mathrm{ml}$ of the mixture $\mathrm{CHCl}_{3}-\mathrm{MeOH}$ 7:3. In $5 \mathrm{~min}$ the mixture was 
treated as described above. Detritylated trimer was isolated by chromatography in the gradient $0-2 \%$ of methanol in $\mathrm{CHCl}_{3}$ (yield $2.32 \mathrm{~g}, 1.17 \mathrm{mmol}, 83 \%$ ). The product was dissolved in dioxane-conc. $\mathrm{NH}_{3}$ 2:3 mixture $(100 \mathrm{ml})$ and left for 3 days at room temperature. Solution was evaporated, the residue was treated with $25 \mathrm{ml}$ of $0.01 \mathrm{M}$ TEAB (pH 7.5) and $25 \mathrm{ml}$ of $\mathrm{CHCl}_{3}$. Organic layer was separated. Product was isolated by ion-exchange chromatography and transformed into potassium salt as described in 1b. $632 \mathrm{mg}$ of $1 \mathrm{a}(0.63$ mmol) were obtained. Deblocking yield equaled 54\%, overall yield was $25 \%$ from $\mathrm{OH}$-component $3 \mathrm{a} . \mathrm{R}_{\mathrm{f}} 0$ (A), 0.70 (B). $\lambda_{\max }\left(\mathrm{H}_{2} \mathrm{O}\right) 259 \mathrm{~nm} \quad\left(\varepsilon=3.76 \times 10^{4}\right)$. ESI-MS: $m / z 926.4\left[(\mathrm{M}+\mathrm{H})^{+}\right]$.

Adenylyl-(2'-5')-adenylyl-(2'-5')-(3'-deoxyadenosi ne)(1c). Cordycepin analogue was obtained by both methods described above using EPO or MeIm nucleophilic catalysts. $\mathrm{R}_{\mathrm{f}} 0$ (A), 0.71 (B). $\lambda_{\max }\left(\mathrm{H}_{2} \mathrm{O}\right)$ $259 \mathrm{~nm}\left(\varepsilon=3.75 \cdot 10^{4}\right)$. ESI-MS: $m / z 910.3\left[(\mathrm{M}+\mathrm{H})^{+}\right]$.

Results and Discussion. O-nucleophilic catalysis of coupling reactions in oligonucleotide synthesis has some advantages over traditional N-nucleophilic catalysis with the reagents like methylimidazole. First of all, it is much higher reaction speed, and lower level of side reactions resulting from low basicity of reagents. N-oxides are much less basic compounds than corresponding pyridines $\left(\Delta \mathrm{pK}_{\mathrm{a}}=4-6\right)$, but at the same time they are 50-100 times more reactive catalysts [20]. High efficiency of O-nucleophilic catalysis was previously demonstrated in the synthesis of oligodeoxyribonucleotides. In this case, almost quantitative coupling is achieved in 2-3 min, as compared to 10-15 min with methylimidazole catalysis [21] (for intramolecular catalysis the speed is even higher [22, 23]). Synthesis conditions in the preparation of quite labile oligoribonucleotides should be as mild as possible which can be provided by O-nucleophilic catalysts combining high nucleophilicity with low basicity. In the present work O-nucleophilic catalysis was applied to the synthesis of triadenylate 1a and its analogues containing an epoxy group or cordycepin residue at $3^{\prime}$-end $(1 \mathrm{~b}, 1 \mathrm{c})$.

Trinucleotides 1a-c were synthesized by modified phosphotriester approach in the solution (Scheme). $6-\mathrm{N}, 5^{\prime}, 3^{\prime}$-O-protected phosphodiester 2 was used as a nucleotide component in all cases. To prepare it,
5'-O-dimethoxytrityl-N-6-benzoyladenosine was selectively benzoylated at $3^{\prime}$-hydroxyl $[26,27]$, and then $2^{\prime}$-hydroxy group of $3^{\prime}$-benzoate was phosphorylated by $o$-chlorophenylphosphoditriazolide in acetonitrile [28]. OH-components were suitably protected nucleosides 3a-c. Protected adenosine 3a was $3^{\prime}$-terminal nucleoside in the synthesis of natural trimer $1 \mathrm{a}$, and $3^{\prime}-\mathrm{O}, \mathrm{N}$-protected cordycepin $3 \mathrm{c}$ in the synthesis of cordycepin analogue of 2-5A. These nucleosides were obtained by known methods of nucleoside chemistry. In the synthesis of epoxy-2-5A N-protected anhydroadenosine $3 \mathrm{~b}$ was used as $\mathrm{OH}$-component. It was obtained by selective benzoylation of 2',3'-anhydroadenosine [29] at exocyclic amino group using silyl transient protection method [28]. In our case trimethylchlorosilane was used as silylating agent, whereas patent [12] applied more expensive hexamethldisilazane for this purpose.

Activating reagent triisopropylbenzenesulfonyl chloride (TPSCl, 2.5 eq. to P-component) and coupling catalyst 4-ethoxypyridine N-oxide (EPO, [21]) were used in the synthesis of triadenylates from synthons 2 and 3 a-c. 3 eq. of $\mathrm{N}$-oxide to TPSCl and $25 \%$ excess of P-component over nucleoside component were introduced in the reaction. Reactions were performed in pyridine or acetonitrile. The second coupling was carried out in acetonitrile, whereas the first one was performed in pyridine due to insufficient solubility of starting nucleosides in $\mathrm{CH}_{3} \mathrm{CN}$. Coupling reactions were fast (less than $5 \mathrm{~min}$ ), and high yields were achieved. Dimethoxytrityl group was removed by $p$-toluenesulfonic acid. At all stages the products were isolated by silica gel chromatography. Deblocking of detritylated epoxy-trimer was performed in 2 stages: it was treated with $0.15 \mathrm{M}$ solution of 2-nitrobenzaldoxime (NBA) in dioxane-triethylamine water 1:1:1 mixture (10 eq. of oxime per phosphate group) to remove chlorophenyl phosphate-protecting groups [28, 30], and then O- and N-benzoyl groups were cleaved by ammonolysis. Experiments showed that the epoxy group in $2^{\prime}, 3^{\prime}$-anhydroadenosine was stable both to oximate treatment and ammonolysis.

Protocol of the synthesis of epoxy derivative $1 \mathrm{~b}$ with EPO is presented in Materials and Methods. Natural trimer 1a and its analogue 1c containing 3 '-terminal cordycepin residue were synthesised in the same way. 


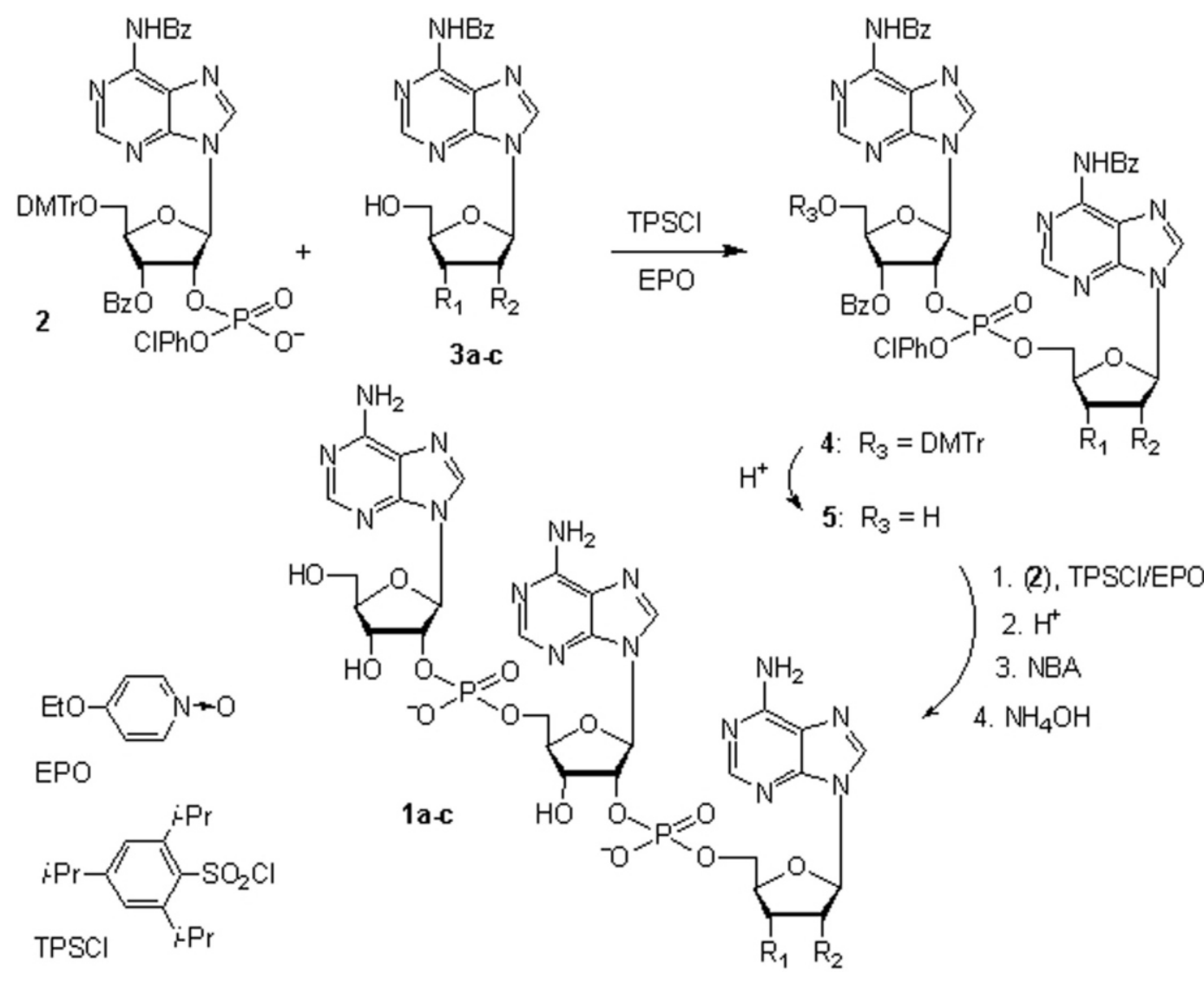

General scheme of the synthesis of (2'-5')-oligoadenylates. $\mathrm{Bz}$ - benzoyl, ClPh $o$-chlorophenyl, DMTr - dimethoxytrityl, NBA -2-nitrobenzaldoxime.
High rate and yields of the reaction were observed in all cases. Final deblocking of $1 \mathrm{a}$ and $1 \mathrm{c}$ was performed in one stage without oximate treatment, using only the ammonolysis of detritylated trimers. Additional treatment with oxime resulted in insignificant increase of the yield of deblocked oligomers (this was the case for epoxy analogue $1 \mathrm{~b}$ as well). After complete removal of protecting groups trimers 1a-c were purified by anion-exchange chromatography on Molselect DEAE-25 sorbent in 0.01-0.3 M gradient of concentration of TEAB ( $\mathrm{pH} 7.5)$. Potassium salts of $\left(2^{\prime}-5^{\prime}\right)$-triadenylates were obtained by the precipitation of ethanolic solutions of triethylammonium salts of trimers with potassium iodide solution in acetone. The yields of trimers la-c were $29-35 \%$ based on corresponding starting nucleoside components $3 \mathrm{a}-\mathrm{c}$.

For comparison, trimers 1a-c were prepared also by classic method [31] using coupling reagent TPSCl and $\mathrm{N}$-nucleophilic catalyst methylimidazole. The repre- sentative synthetic protocol for trimer 1a is provided in experimental part. The synthesis of 1a-c with MeIm was generally performed as we described before [14]. At all stages the same reagents, their concentration and ratio were used as in the EPO-catalyzed synthesis of corresponding trimers. Under the same synthetic conditions, methylimidazole provided substantially lower coupling yields (up to $85 \%$ ) and total yields of final oligomers (21-25\%), as compared with EPO. Couplings in the presence of MeIm resulted in the formation of less clean reaction mixtures, with several times longer coupling reactions (10-15 min). Thus, overall efficiency of 2-5A synthesis using $\mathrm{N}$-oxide catalysis appeared to be considerably higher than that with MeIm.

The data on the yields of individual coupling reactions and final products synthesized under various conditions are presented in the Table. All triadenylates are white powders soluble in water and practically insoluble in organic solvents. The purity of compounds pre- 
Yields of individual coupling reactions and final yields of (2'-5')-trinucleotides

\begin{tabular}{|c|c|c|c|c|c|c|}
\hline \multirow{3}{*}{ Compound } & \multicolumn{6}{|c|}{ Yield, \% } \\
\hline & \multicolumn{3}{|c|}{ Synthesis with EPO } & \multicolumn{3}{|c|}{ Synthesis with MeIm } \\
\hline & $1^{\text {st }}$ coupling & $2^{\text {nd }}$ coupling & final & 1st coupling & 2nd coupling & final \\
\hline 2-5ApApA (1a) & 90 & 87 & 31 & 83 & 80 & 25 \\
\hline $2-5 \mathrm{ApApA}_{\text {epoxy }}(1 \mathrm{~b})$ & 91 & 86 & 35 & 85 & 81 & 24 \\
\hline
\end{tabular}

pared by both methods was $95-96 \%$, according to reverse-phase HPLC. Their structures were confirmed by mass-spectrometric analysis (ESI-MS).

In conclusion, the use of $\mathrm{O}$-nucleophilic catalysis of internucleotide coupling reaction in the phosphotriester synthesis of oligoribonucleotides allowed achieving a high speed and yield of coupling reactions and overall synthesis efficiency. The effectiveness of this reagent in the synthesis of $\left(2^{\prime}-5^{\prime}\right)$-oligoadenylates exceeds that of the classical nucleophilic catalyst of nucleic acids chemistry, N-methylimidazole, substantially.

Authors are grateful to Academician G.H. Matsuka for valuable discussions, Dr Z.Yu. Tkachuk (Institute of Molecular Biology and Genetics, NAS of Ukraine) for kindly provided sample of cordycepin, and Dr S. Richelme (Service de Spectrometrie de Masse, Universite Paul Sabatier, Toulouse, France) for performing mass-spectrometric analysis of compounds.

\section{И. Я. Дубей, Л. В. Дубей}

Синтез (2'-5')-триаденилатов и их аналогов с

использованием О-нуклеофильного катализа реакции межнуклеотидной конденсации

Резюме

Осуществлен синтез (2'-5')-триаденилата и его аналогов, содержащчх 3'-концевой остаток эпоксиаденозина и кордицепина, фосфотриэфирным методом в присутствии О-нуклеофильного катализатора реакции конденсации $\mathrm{N}$-оксида 4-этоксипиридина (ЕРО). Реакиии конденсации проходили с высокой скоростью (до 5 мин) и выходом (86-92\%). Выходы реакиий в присутствии $N$-метилимидазола были заметно ниже (80-85\%), а суммарный выход триаденилатов в этом случае составлял 21-25\% против 29-35\% при использовании ЕРО.

Ключевые слова: (2'-5')-олигоаденилаты, аналоги олигонуклеотидов, фосфотриэфирный синтез, нуклеофильный катализ, $N$-оксиды пиридинов.

\section{REFERENCES}

1. Player M. R., Torrence P. F. The 2-5A system: modulation of viral and cellular processes through acceleration of RNA degradation // Pharmacol. Ther.-1998.-78, N 2.-P. 55-113.

2. Adah S. A., Bayly S. F., Cramer H., Silverman R. H., Torrence $P$. F. Chemistry and biochemistry of $2^{\prime}, 5^{\prime}$-oligoadenylatebased antisense strategy // Curr. Med. Chem.-2001.-8, N 10.-P. 1189-1212.

3. Malmgaard $L$. Induction and regulation of IFNs during viral infections // J. Interferon Cytokine Res.-2004.-24, N 8.P. 439-454.

4. Liang S. L., Quirk D., Zhou A. RNase L: its biological roles and regulation // IUBMB Life.-2006.-58, N 9.-P. 508-514.

5. Castelli J., Wood K. A., Youle R. J. The 2-5A system in viral infection and apoptosis // Biomed. Pharmacother.-1998.-52, N 9.-P. 386-390.

6. Lesiak K., Torrence P. F. Efficient functionalization of 2',5'-oligoadenylates with sulfur // Bioconjugate Chem.1997.-8, N 2.-P. 199-203.

7. Ueno Y., Ishihara S., Ito Y., Kitade $Y$. Synthesis of 2',5'-oligoadenylate analogs containing an adenine acyclonucleoside and their ability to activate human RNase L // Bioorg. Med. Chem. Lett.-2004.-14, N 17.-P. 4431-4434.

8. Pat. EP156870. Novel 2',5'-oligoadenylic acids analogues / M. Kozumi, K. Morita // Publ. 2005.

9. Ueno Y., Kato Y., Okatani S., Ishida N., Nakanishi M., Kitade $Y$. Synthesis of antisense oligonucleotides carrying modified 2-5A molecules at their 5'-termini and their properties // Bioconjugate Chem.-2003.-14, N 3.-P. 690-696.

10. Sawai H., Hirano A., Mori H., Shinozuka K., Dong B., Silverman R. H. Synthesis, characterization, and biological properties of 8-azido- and 8-amino-substituted 2',5'oligoadenylates // J. Med. Chem.-2003.-46, N 23.-P. 49264932.

11. Kalinichenko E. N., Podkopaeva T. L., Budko E. V., Seela F., Dong B., Silverman R., Vepsalainen J., Torrence P. F., Mikhailopulo I. A. 3-Deazaadenosine analogues of p5'A2'p5'A2'p5'A: synthesis, stereochemistry, and the roles of adenine ring nitrogen-3 in the interaction with RNase L // Bioorg. Med. Chem.-2004.-12, N 13.-P. 3637-3647.

12. Pat. USA 5571799. (2'-5')Oligoadenylate analogues useful as inhibitors of host-vs.-graft response / Z. Tkachuk, E. Kvasyuk, G. Matsuka, I. Mikhailopulo // Publ. 1996.

13. Сидорик Л. Л., Дубей И. Я., Бобык В. И., Козлов А. В., Федоркова О. М., Ковеня Т. В., Рябенко Д. В., Сергиенко О. В., Трунина И. В., Погребной П. В., Маиука Г. Х. Терапевтические эффекты действия различных доз 2'-5'-олигоаденилата при экспериментальном миозин-индуцирован- 
ном повреждении миокарда // Доп. НАН України.-2001.№ 9.-C. 161-165.

14. Ткачук 3. Ю., Дубей І. Я., Яковенко Т. Г., Семерникова Л. I., Шаповал С. О., Артеменко В. С., Дубей Л. В. Синтез $2^{\prime}-5$-олігоаденілатів та їхній вплив на проліферацію і міграцію стовбурових клітин кісткового мозку мишей in vitro та in vivo // Біополімери і клітина.-2007.-23, № 1.C. $14-20$.

15. Ткачук 3. Ю., Ткачук В. В.,Ткачук Л. В., Семерникова Л. І., Мацука Г. Х. Вплив 2'-5' олігоаденілатів та їх аналогів на рівень циклічних нуклеотидів в системах in vivo та in vitro // Біополімери і клітина.-2001.-17, № 5.-C. 411-416.

16. Mueller W. E. G., Weiler B. E., Charubala R., Pfleiderer W., Leserman L., Sobol R. W., Suhadolnik R. J., Schroeder H. C. Cordycepin analogues of 2',5'-oligoadenylate inhibit Human Immunodeficiency Virus infection via inhibition of reverse transcriptase // Biochemistry.-1991.-30, N 8.-P. 2027-2033.

17. Pat. USA 5550111. Dual action $2^{\prime}, 5^{\prime}$-oligoadenylate antiviral derivatives and uses thereof / R. J. Suhadolnik, W. Pfleiderer // Publ. 1996.

18. Black P. L., Henderson E. E., Pfleiderer W., Charubala R. Suhadolnik R. J. 2',5-Oligoadenylate trimer core and the cordycepin analog augment the tumoricidal activity of human natural killer cells // J. Immunol.-1984.-133, N 5.-P. $2773-$ 2777.

19. Hubbell H. R., Pequignot E. C., Willis D. H., Lee C., Suhadolnik R. J. Differential antiproliferative actions of 2',5' oligo A trimer core and its cordycepin analogue on human tumor cells // Int. J. Cancer.-1985.-36, N 3.-P. 389-394.

20. Савелова В. А., Белоусова И. А., Литвиненко Л. М., Яковец $A$. $A$. Сопоставление нуклеофильной реакционной способности 4-N,N-диметиламинопиридина и его N-окиси // Докл. АН СССР.-1984.-274, № 6.-С. 1393-1398.

21. Efimov V. A., Chakhmakhcheva O. G., Ovchinnikov Yu. A. Improved rapid phosphotriester synthesis of oligodeoxyribonucleotides using oxygen-nucleophilic catalysts // Nucl. Acids Res.-1985.-13, N 10.-P. 3651-3666.

22. Efimov V. A., Buryakova A. A., Dubey I. Y., Polushin N. N., Chakhmakhcheva O. G., Ovchinnikov Yu. A. Application of new catalytic phosphate protecting groups for the highly efficient phosphotriester oligonucleotide synthesis // Nucl. Acids Res.-1986.-14, N 16.-P. 6525-6540.

23. Efimov V. A., Buryakova A. A., Dubey I. Y., Polushin N. N., Chakhmakhcheva O. G., Ovchinnikov Yu. A. Phosphotriester synthesis of oligonucleotides with the use of $\mathrm{N}$ - and O-nucleophilic intramolecular catalysis // Nucleosides and Nucleotides.-1987.-6, N 1-2.-P. 279-282.

24. Ochiai E. Recent Japanese work on the chemistry of pyridine $\mathrm{N}$-oxide and related compounds // J. Org. Chem.-1953.-18, N 5.-P. 534-551.

25. Katritzky A. R. The preparation of some substituted pyridine 1-oxides // J. Chem. Soc.-1956.-7.-P. 2404-2408.

26. Kvasyuk E. I., Kulak T. I., Khripach N. B., Mikhailopulo I. A., Uhlmann E., Charubala R., Pfleiderer $W$. Nucleotides XXIV. Preparative synthesis of trimeric (2'-5')oligoadenylic acid // Synthesis.-1987.-N 6.-P. 535-541.

27. А. с. СССР 1541214 . Способ получения 5'-О-монометокситритил-N6,3'-О-дибензоиладенозина / Т. Л. Подкопаева, Е. Н. Калиниченко, И. А. Михайлопуло // Б. и.-1990.-№ 5.-С. 121.

28. Oligonucleotide synthesis: a practical approach / Ed. M. J. Gait.-Oxford: IRL press, 1984.-218 p.

29. Robins M. J., Fouron Y., Mengel R. Nucleic acid related compounds. 11. Adenosine 2',3'-ribo-epoxide. Synthesis, intramolecular degradation and transformation into 3'-substituted xylofuranosyl nucleosides and lyxo-epoxide // J. Org. Chem.-1974.-39, N 11.-P. 1564-1570.

30. Reese C. B., Zard L. Some observations relating to the oximate ion promoted unblocking of oligonucleotide aryl esters // Nucl. Acids Res.-1981.-9, N 18.-P. 4611-4626.

31. Efimov V. A., Reverdatto S. V., Chakhmakhcheva O. G. New effective method for the synthesis of oligonucleotides via phosphotriester intermediates // Nucl. Acids Res.-1982.-10, N 21.-P. 6675-6694. 